\title{
Antioxidant Effects of Cinnamomum cassia Bark Extract and its Effectiveness as a Cosmetics Ingredient
}

\author{
Young Suk Lee, Min Jeong Ryu \\ Department of Cosmetology Science, Nambu University, Gwangju, Korea
}

\author{
"Corresponding author: Min Jeong Ryu, \\ Department of Cosmetology Science, \\ Nambu University, 23 advanced Jungang- \\ ro, Gwangsan-gu, Gwangju 62271, Korea \\ Tel.: +8262970 0137 \\ Fax: +82629726200 \\ Email: jemine0806@hanmail.net
}

Received November 15, 2018

Revised January 11, 2019

Accepted January 17, 2019

Published March 30, 2019

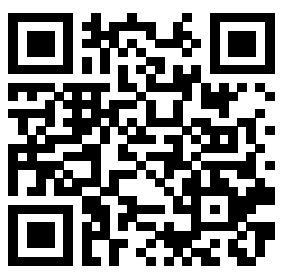

\begin{abstract}
Purpose: This study examines potential abilities and commercial values of Cinnamon extract as bioactive and cosmetics ingredients. Methods: Cinnamomum cassia bark was extracted with hot water and $70 \%$ ethanol to examine its antioxidant effects through its total polyphenol, flavonoid content, 2,2-diphenyl-1-picrylhydrazyl (DPPH) radical scavenging activity, and (2,2-azinobis (3-ethylbenzothiazoline-6-sulfonic acid) ABTS radical scavenging activity. Also, this study examined its nitric oxide (NO) inhibition effect through RAW 264.7 cells into which inflammatory reaction was induced by lipopolysaccharides (LPS), and antihistamine activity in the RBL$2 \mathrm{H} 3$ cells. The antibacterial effects of Cinnamomum cassia bark extract on 8 types of bacteria were also studied. Results: As a result of measuring the antioxidant effect, the total polyphenol contents were 90.12 and $113.07 \mu \mathrm{g} / \mathrm{mL}$, respectively, while the total flavonoid contents were 36.42 and $54.31 \mu \mathrm{g} / \mathrm{mL}$, respectively. The DPPH scavenging effect was confirmed as $84.93 \%$ in the hot water extract and $90.25 \%$ in the ethanol extract for $400 \mu \mathrm{g} / \mathrm{mL}$. The ABTS radical scavenging effect was $82.20 \%$ in the hot water extract and $92.21 \%$ in the ethanol extract for $400 \mu g /$ $\mathrm{mL}$. Upon measuring the NO inhibitive effect through the RAW 264.7 cells into which inflammation reaction was induced by LPS, the NO generation decreased to 14.57 $\mu \mathrm{M}$ in the hot water extract and $10.15 \mu \mathrm{M}$ in the ethanol extract in the concentration of $100 \mu \mathrm{g} / \mathrm{mL}$. This result, compared to the increase up to $20.11 \mu \mathrm{M}$ by LPS, shows the NO inhibitive effect of Cinnamoum cassia bark extract. As a result of measuring the antihistamine activity in the RBL-2H3 cells, $\beta$-hexosaminidase increased to $176.21 \%$ by lgE-NDP whereas it was $117.25 \%$ in the hot water extract and $100.09 \%$ in the ethanol extract in the concentration of $100 \mu \mathrm{g} / \mathrm{mL}$, confirming the inhibitive effect on $\beta$-hexosaminidase discharge. The antibacterial effect was confirmed on all bacteria through the measurement on the Cinnamomum cassia Bark extract on eight types of bacteria. Particularly, the antibacterial effect of the hot water extract and ethanol extract was found to be high in Staphylococcus epidermidis ( $S$. epidermidis), Pityrosporum ovale (P. ovale). Conclusion: Cinnamomum cassia bark extract is deemed prospective as a natural functional cosmetics' ingredient with excellent antioxidant, anti-inflammatory, antihistamine inhibitive and antibacterial effects.
\end{abstract}

Keywords: Cinnamomum cassia bark, Antioxidant, Anti-inflammation, Antibacterial effect, Cosmetics

\section{Introduction}

최근 산업화, 도시화가 심화되면서 주거 환경 및 식생활의 변 화, 유전적 영향, 환경오염 등에 의해 발생되는 화학적, 생물학
적 유해인자들에 대한 노출에 의해 다양한 연령층에서 면역조절 이상으로 유발된 염증 반응이나 알러지 및 아토피 질환과 같은 염증성 질환의 발생이 크게 증가하고 있다(Lee et al., 2017a).

염증은 체내의 세포가 인체를 보호하기 위하여 외부 자극에 
의한 피부 손상에 대응하여 반응하는 현상을 말한다. 염증이 일 어난 부위에서는 홍반, 부종, 수포 및 열감과 소양증 등의 증상 이 관찰된다(Nam \& Kim, 2015).

체내 염증과정에서 활성자유종(reactive radical species) 의 일종인 $\mathrm{NO}$ 는 대식세포와 같은 면역세포에 의해 생성되어 각 종 생리 및 병리적 과정에 있어 중요한 역할을 하는 것으로 알려 져 있다. NO는 매우 불안정한 화합물로서 LPS와 같은 염증유 발물질에 의한 NO 생성효소인 inducide nitric oxide synthase (iNOS)의 활성화를 통해 생성된다(Lee et al., 2006).

아토피 피부염은 만성재발성 염증성 피부질환으로 대개 유·소 아기에 발병하나 최근 청소년기나 성인에 있어서도 유병률이 높 아지고 있다. 특히 장기간의 치료를 요하며 완치가 어렵고 주로 노출된 부위에 발생하면서 중증화하여 삶의 질에도 많은 영향을 미친다(Kim, 2010).

알러지 반응은 염증성 질환의 한 종류로 mast cell이 탈과립 되어 일어나는데 이때 히스타민이 분비 되게 된다. 히스타민은 mast cell에서 합성, 저장되고 급성 염증반응에 많은 영향을 끼 치는 것으로 알려져 있으며, $\beta$-hexosaminidase는 히스타민과 mast cell내에 함께 존재하는 효소로 탈과립에 의해 누출되는 히 스타민의 양과 비례하는 것으로 알려져 있어 항 알러지 효과 확 인의 지표로서 사용되고 있다(Hong et al., 2014).

피부에 존재하는 상재구균들은 땀에서 분비되는 면역항체와 결합하여 피부면역력을 높여준다. 건강한 피부에서는 유익균 $80 \%$, 유해균 $20 \%$ 의 비율이 유지되며 약산성을 이루며 균형을 유지한다. 이때 잘못된 세정습관이나 과도한 유지공급, 신체의 리듬과 불안정한 호르몬생성은 과도한 피지분비를 유도하여 항 상성을 깨지게 한다. 이로 인한 피지선의 막힘은 모낭내의 미생 물을 번식하기에 알맞은 조건을 형성하며 혐기성균, 호기성구균, 진균 등이 번식하게 된다(Lee et al., 2016).

여드름은 여러 가지 원인 중에서 여드름균(Propionibacterium acnes, P. acnes)의 존재 때문으로 이것은 여드름 병변 악화의 중요한 원인으로 설명된다. 피지선내에 여드름 균의 증식이 많아 짐에 따라 여드름 균에 의해 피지를 구성하고 있는 트리글리세라 이드가 자유 지방산으로 전환되어서 자극원으로 작용하거나. 면 포유발성(comedogenic) 물질로 작용하여 여드름 생성을 촉진시 킨다, 또한 더욱 진행되어 염증반응까지 수반하게 된다(Cho et al., 2008).

비듬(dandruff)은 붉거나 진물 같은 염증증상 없이 두피에 각 질세포가 쌀겨모양으로 심하게 일어나는 현상이다. 비듬을 질병 분류에 논란이 있으나 가장 흔하고 경한 지루피부염의 형태로 알 려져 있으며, 지성 인설이나 건성양 발진, 삼출액, 두꺼운 가피 를 수반하는 심한 경우도 있다(Kim et al,. 2007).

현재 주로 사용되는 항생제들은 benzoyl peroxide, retinoid, triclosan, tetracycline, clindamycin, erythromycin 등이 있
지만, 이들 항생제에 대한 내성균의 출현이나 조직, 장기 손상, 과민반응 등과 같은 부작용이 큰 문제로 대두되고 있는 실정이 다. 이러한 문제점을 극복하기 위하여 최근에는 독성이나 부작용 이 없으면서 강력한 항균 활성 및 항염 효능을 함유하고 있는 천 연물들을 규명하기 위한 연구가 국내외에서 활발이 진행되고 있 는 추세이다(Kim \& Park, 2017; Kim et al., 2006; Lee et al., 2018; Shim, 2018).

계피(Cinnamomum cassia)는 상록교목으로 약 7-8 $\mathrm{m}$ 에 달 하는 식물로, 산야에서 재배되며, 모양은 반관상, 반통상 또는 한족으로 말려 들어가 있는 관상의 껍질인데, 대부분 조각 형태 로, 크기는 다양하다. 바깥면은 짙은 적갈색이고 내면은 평탄하 나 역시 적갈색이고 파절이 용이하다. 특이한 향이 있고 맛은 처 음에 약간 달고 매우며 나중에는 점액성을 띄고 떫다(Park et al., 2012). 약효는 건위, 두통, 감기, 온비위, 통혈맥, 주심통이 며, 방향제와 향신료 등에 사용한다(Kim \& Song, 2001). 계피 의 정유 성분 중에서 방향족 화합물인 cinnamic aldehyde는 항 산화와 항균에 효과가 있고 정유성분의 $80 \%$ 정도를 차지하며, 근래에는 음료, 껌, 치약 및 화장품의 제조에 널리 이용되고 있 다(Huh \& Shim, 2017).

따라서 본 연구에서는 계피에서 열수 및 $70 \%$ 주정 에탄올로 추출을 실시하여 얻은 추출물에 대해 화장품 소재로서의 가능성 을 시험하였다. 계피 추출물의 항산화 효과를 확인하기 위하여 총 폴리페놀 및 플라보노이드 함량, DPPH radical 및 ABTS 라 디칼 소거활성을 시험하였다. 그리고 항염 효과를 확인하기 위하 여 LPS로 염증반응이 유도된 RAW 264.7 세포를 통해 NO 생성 저해 효과와 RBL- $2 \mathrm{H} 3$ 세포에서 항히스타민 활성을 알아보았다. 마지막으로 8 균에 대한 계피 추출물의 항균효과를 확인하였다.

\section{Methods}

\section{1. 시료 제조}

본 실험에 사용한 계피(Cinnamomum cassia bark)는 경동 시장에서 한국산을 구입하여 분쇄하여 사용하였다. 열수 추출방 법은 계피(water extraction, $\mathrm{WE}$ )을 $60^{\circ} \mathrm{C}$ 에서 증류수를 가해서 $24 \mathrm{~h}$ 추출하였고, 에탄올 추출방법은 계피(ethanol extraction, $\mathrm{EE})$ 을 $60^{\circ} \mathrm{C}$ 에서 $70 \%$ 에탄올을 가해서 $24 \mathrm{~h}$ 추출하고, 추출액 을 여과(Whatman filter paper No.1; Whatman, UK)한 후 에 회전식 감압농축기(EYELA N-1000; Tokyo Rikakikai Co, Japan)로 농축한 후, 동결건조기 (PVTFA 10AT; ILSIN, Korea)에 $72 \mathrm{~h}$ 동안 동결 건조하여 분말로 만들어 실험을 진행 하였다. 


\section{2. 총 폴리페놀 함량}

총 폴리페놀 함량은 Folin \& Denis (1915) 방법에 따라, 계피 추출물 $(1 \mathrm{mg} / \mathrm{mL}) 50 \mu \mathrm{L}$ 에 증류수 $650 \mu \mathrm{L}$ 넣고 Folin-Denis' reagent $50 \mu \mathrm{L}$ 를 가하여 $3 \mathrm{~min}$ 동안 실온에서 반응시킨다. 반 응시킨 후 $10 \%$ sodium carbonate $\left(\mathrm{Na}_{2} \mathrm{CO}_{3}\right.$; Sigma-Aldrich, $\mathrm{USA}$ )포화용액을 $100 \mu \mathrm{L}$ 첨가하고, 최종 볼륨을 $1 \mathrm{~mL}$ 맞추기 위해 증류수 $150 \mu \mathrm{L}$ 넣어 잘 혼합시켰다. $37^{\circ} \mathrm{C}$ water bath에 $1 \mathrm{~h}$ 반응시킨 후 Microplate Reader (iMARK ${ }^{\mathrm{TM}}$, BIO-RAD, $\mathrm{USA}$ )를 이용하여 $725 \mathrm{~nm}$ 에서 흡광도를 측정하였다. 표준곡선 은 tannic acid 농도 0-500 $\mu \mathrm{g} / \mathrm{mL}$ 이 되도록 하고 이로부터 총 폴리페놀 함량을 구하였다.

\section{3. 총 플라보노이드 함량}

총 플라보노이드 함량은 계피 추출물 $(1 \mathrm{mg} / \mathrm{mL}) 100 \mu \mathrm{L}$ 에 1 $\mathrm{mL}$ diethylene glycol을 첨가하고, 다시 $1 \mathrm{~N}$ sodium hydroxide $\left(\mathrm{NaOH}\right.$; Sigma-Aldrich) $100 \mu \mathrm{L}$ 넣어 잘 혼합시켜 $37^{\circ} \mathrm{C}$ water bath에 $1 \mathrm{~h}$ 반응시킨 후 Microplate Reader (iMARK ${ }^{\mathrm{TM}}$ ) 을 이용하여 $420 \mathrm{~nm}$ 에서 흡광도를 측정하였다. 표준곡선은 naringin 농도를 0-300 $\mu \mathrm{g} / \mathrm{mL}$ 이 되도록 하여 작성하고 이로부 터 총 플라보노이드 함량을 구하였다.

\section{4. 전자 공여능}

$\mathrm{DPPH}$ radical을 이용한 항산화 활성은 Blois (1958) 방법을 약간 변형하여 사용하였다. $1 \mathrm{mM} \mathrm{DPPH}$ 용액 $100 \mu \mathrm{L}$ 와 계피 추 출물(15.7-500 $\mu \mathrm{g} / \mathrm{mL})$ 을 $100 \mu \mathrm{L}$ 씩 취하여 혼합한 후 $30 \mathrm{~min}$ 암 상태에서 방치한 후 잔존 radical 농도를 Microplate Reader $\left(\mathrm{iMARK}^{\mathrm{TM}}\right.$ )를 이용하여 $517 \mathrm{~nm}$ 에서 측정하였다. 활성비교를 위 하여 항산화 물질로 잘 알려진 butylated hydoxytoluene (BHT), ascorbic acid와 비교하였다. 전자공여능(\%)은 (1-시료의 흡광 도/대조군의 흡광도 $) \times 100$ 에 의하여 산출하였다.

\section{ABTS 라디칼 소거활성 측정}

2,2'-azinobis-(3-ethyl-benzothiazoline-6-sulphonic acid (ABTS) 와 potassium persulfate를 혼합하여 암소에 두면 $\mathrm{ABTS}$ 라디칼이 생성되는데 추출물의 항산화 물질과 반응하여 양이온이 소거됨으로써 특유의 청록색이 탈색되며 이의 흡광도 를 측정하여 항산화 능력을 측정할 수 있다. 시험 용액은 증류수 에 $7 \mathrm{mM} \mathrm{ABTS}$ 와 $2.45 \mathrm{mM}$ potassium persulfate를 첨가하여 상온에서 $16 \mathrm{~h}$ 배양하여 ABTS 양이온을 생성시킨 후 $734 \mathrm{~nm}$ 에서 흡광도의 값이 0.7 이하가 되도록 희석하여 제조하였다. 그 다음 ABTS 용액 $100 \mu \mathrm{L}$ 에 시료 용액 $100 \mu \mathrm{L}$ 을 가한 후 $6 \mathrm{~min}$ 후에 흡광도를 측정하였다. 음성대조군 $(2.45 \mathrm{mM}$ potassium persulfate buffer)의 흡광도와 비교하여 흡광도를 감소시키는 정도를 $\%$ 로 나타내었다.

\section{RAW 264.7 세포에서LPS에 대한 항염증 효과 측정}

1) 세포배양

마우스 대식세포주인 RAW 264.7 세포는 한국세포주은행 (Korean Cell Line Bank, KCLB)에서 분양 받아 사용하였으 며 세포는 $10 \% \mathrm{FBS}$ 과 $\mathrm{P} / \mathrm{S}$ 을 첨가한 $\mathrm{DMEM}$ 배지에 $37^{\circ} \mathrm{C}, 5 \%$ $\mathrm{CO}_{2}$ 조건에서 배양하였다. 세포 배양배지는 세포가 $80 \%$ 이상 자란 시점에서 2-3일마다 교환하였다.

\section{2) 세포 생존율 측정}

RAW 264.7 대식세포의 생존율 측정은 96 well plate의 각 well에 logarithmic phase에 도달한 세포를 $1 \times 10^{5}$ cells/well 의 농도가 되도록 조절하여 분주하여 $24 \mathrm{~h}$ 배양하여 부착화 및 안정화를 시행하였다. $24 \mathrm{~h}$ 배양이 끝난 후 계피 추출물을 최 종 농도 1-200 $\mu \mathrm{g} / \mathrm{mL}$ 가 되도록 배양액에 희석하여 부착 및 안 정화된 세포에 공급하고 $24 \mathrm{~h}$ 동안 배양하였다. 배양완료 후 각 well에 MTT 용액( $5 \mathrm{mg} / \mathrm{mL}$ in phosphate buffered saline) 을 $10 \mu \mathrm{L}$ 씩 가해주고, 다시 $37^{\circ} \mathrm{C}, 5 \% \mathrm{CO}_{2}$ 의 습윤 배양기에서 $4 \mathrm{~h}$ 동안 반응하여 MTT가 환원되도록 하였다. 각 well에 생성 된 formazan 결정을 dimethyl sulfoxide $150 \mu \mathrm{L}$ 로 잘 녹여서 Microplate Reader (iMARK ${ }^{\mathrm{TM}}$ )를 이용하여 $540 \mathrm{~nm}$ 에서 흡광 도를 측정하였다.

\section{3) RAW 264.7 세포에서 NO 저해 효과 측정}

$\mathrm{NO}$ 의 기질인 $\mathrm{L}$-알기닌은 $\mathrm{L}-$ 시트룰린과 $\mathrm{NO}$ 로 변하는데, 이 는 빠르게 안정된 이산화질소, 아질산염, 질산염으로 변한다. 그 리스 시약(Griess reagent; $0.5 \%$ 의 sulphanilamide, $2.5 \%$ 의 phosphoric acid 및 $0.5 \%$ 의 naphtylethylendiamide)은 아질 산염과 화학 반응하여 보라색의 아조염을 형성하고 이것은 $\mathrm{NO}$ 의 농도와 일치하기 때문에, 아조염의 농도로부터 아질산염의 농도를 측정하여 $540 \mathrm{~nm}$ 에서 흡광도를 측정하였다(Jo et al., 2011). 계피 추출물의 효과를 확인하기 위하여 RAW 264.7 세 포에 LPS로 자극을 주고 세포 독성이 없는 $1,5,10,20,50$, $100 \mu \mathrm{g} / \mathrm{mL}$ 의 농도로 처리하였다. 생성된 NO의 양은 Griess 시 약을 이용하여 세포 배양액 중에 존재하는 $\mathrm{NO}_{2}{ }^{-}$의 형태로 측정 하였다.

\section{7. 항 히스타민 활성 측정}

\section{1) 세포주 배양}

본 실험에 사용한 Rat basophilic leukemia 세포주인 RBL$2 \mathrm{H} 3$ 세포는 한국 세포주은행(KCLB)에서 분양 받아 사용하였 다. $\mathrm{RBL}-2 \mathrm{H} 3$ 세포는 $\mathrm{MEM}$ 배지에 각각 $10 \%$ fetal bovine serum 과 $1 \%$ streptomycin/penicillin을 넣어 배양액으로 하여 각각 $37^{\circ} \mathrm{C}, 5 \% \mathrm{CO}_{2}$ 의 습윤화된 incubator에서 적응시켜 배양하 였다. 
2) MTT assay에 의한 세포 생존율 측정

항히스타민 활성 측정을 위해 $\mathrm{IgE}$ 로 감작된 세포에 대한 계피 추출물의 독성은 MTT assay 방법으로 측정하였다. $\mathrm{RBL}-2 \mathrm{H} 3$ cell를 24 well plate에 각 well 당 $2 \times 10^{5}$ 개의 세포가 들어가 도록 분주한 다음, well 당 $200 \mathrm{ng} / \mathrm{mL}$ 의 AntiDNP IgE로 감작 시키고 $5 \%$ 의 $\mathrm{CO}_{2}$ 배양기에서 $12 \mathrm{~h}$ 배양한 후 여러 농 도 $(1,5$, $10,20,50,100,200 \mu \mathrm{g} / \mathrm{mL}$ )의 추출물을 세포에 처리 하였다. $12 \mathrm{~h}$ 후 MTT assay 방법으로 측정하였다.

\section{3) 항히스타민 활성 측정}

$\mathrm{RBL}-2 \mathrm{H} 3$ 세포주를 24 well plate에 각 well당 $2 \times 10^{5}$ 개 의 세포가 들어가도록 분주한 다음, well 당 $200 \mathrm{ng} / \mathrm{mL}$ 의 Anti $\mathrm{DNP} \mathrm{IgE}$ 로 감작 시키고 $5 \%$ 의 $\mathrm{CO}_{2}$ 배양기에서 $12 \mathrm{~h}$ 배양시켰 다. 세포주는 siraganian buffer $(119 \mathrm{mM} \mathrm{NaCl}, 5 \mathrm{mM} \mathrm{KCl}$, $0.4 \mathrm{mM} \mathrm{MgCl}$, $25 \mathrm{mM}$ PIPES, $40 \mathrm{mM} \mathrm{NaOH}, \mathrm{pH}$ 7.2) 로 2회 세척한 후 계피 추출물을 농도 별로 첨가한 후 $30 \mathrm{~min}$ $37^{\circ} \mathrm{C}$ 에서 다시 반응 시키고 여기에 DNP-HSA $(250 \mathrm{ng} / \mathrm{mL})$ 를 처리하고 $30 \mathrm{~min}$ 알레르기 반응을 유도한 후 ice bath에서 $10 \mathrm{~min}$ 반응을 정지한 후 $12,000 \mathrm{rpm}$ 에서 $3 \mathrm{~min}$ 원심 분리 하여 상등액만 회수하고 $\beta$-hexosaminidase 측정에 이용하였 다. $\beta$-hexosaminidase 분비 저해 측정은 상등액 $30 \mathrm{~mL}$ 와 1 $\mathrm{mMp}-\mathrm{NAG} 30 \mathrm{~mL}$ 을 혼합한 반응액을 $1 \mathrm{~h}$ 동안에 $37^{\circ} \mathrm{C}$ 에서 반 응시키고 $0.1 \mathrm{M}$ carbonate buffer $250 \mathrm{~mL}$ 를 첨가하여 반응을 종결시키고, ELISA reader (Molecular Devices, USA)를 사용 하여 $405 \mathrm{~nm}$ 에서 흡광도를 측정하였다.

\section{8. 항균 효과 측정}

1) 균주배양

항균 실험에 사용한 미생물 균주를 한국생명공학연구원 생물
자원센터(KCTC/BRC, Korea), 한국미생물보존센터(KCCM, Korea)로 부터 분양 받았다. 실험에 사용한 각 미생물 균주의 균 종과 번호를 Table 1에 정리하였다.

2) paper disc에 의한 추출물의 항균력 분석

추출물의 항균성 물질의 항균 검색은 paper disc법을 사용하 였다. 순수 분리된 각 균주 단일집락을 취해 $10 \mathrm{~mL}$ 균 생육 액 체배지에 접종하여 각각 균주 생육적온에 18-24 h씩 3회 배양 한 후 항균활성 시험 균주로 사용하였다. 각각 시험 균 농도를 $650 \mathrm{~nm}$ 에 optical density (O.D)값 $0.4\left(10^{6} \mathrm{CFU} / \mathrm{mL}\right)$ 가 되 게 한 후 균 접종 평판배지를 만들어 사용하였다. 멸균된 $8 \mathrm{~mm}$ paper disc를 올려놓은 후 추출물을 흡수시킨 다음 적정온도에 서 12-24 h 동안 배양 후 disc 주위의 clear zone을 관찰하였 다.

\section{9. 통계처리}

본 연구의 모든 실험 결과는 3 회 이상 반복하여 평균값으로 나 타내었으며, 통계학적 유의성은 Student's t-test로 분석하였으 며, $p$ value가 0.05 미만일 경우 통계적으로 유의한 것으로 판정 하였다 $\left({ }^{*} p<0.05,{ }^{* *} p<0.01\right)$.

\section{Results and Discussion}

\section{1. 총 폴리페놀 및 총 플라보노이드 함량}

각종 천연물로부터 분리된 천연의 항산화제 중에서 식물에 다 량 존재하고 있는 페놀성 화합물과 플라보노이드 등은 항산화, 항균, 항염증 작용 등 다양한 생리활성 기능을 가지어 있어 화장 품 성분으로 이용 되고 있다(Kim \& Jang, 2016). 본 연구에서

Table 1. List of microorganisms used for antimicrobial experiment

\begin{tabular}{lcccc}
\hline Strains & Culture collection & Gram strain & Media & Temperature $\left({ }^{\circ} \mathrm{C}\right)$ \\
Staphylococcus epidermidis & KCCM 35494 & Gram $(+)$ & TSB & 37 \\
Staphylococcus aureus & KCTC 3881 & Gram (+) & TSB & 37 \\
Propionibacterium acnes & KCTC 3329 & Gram (+) & RCM & 37 \\
Escherichia coli & KCCM 11547 & Gram (-) & LB & 37 \\
Pityrosporum ovale & KCCM 12679 & Yeast & YMB & 37 \\
Malassezia furfur & KCTC 7743 & Yeast & YMB & 30 \\
Candida albicans & KCTC 7965 & Yeast & LB & 37 \\
Trichophyton mentagrophytes & KCCM 11950 & Fungl & SGB & 26 \\
\hline
\end{tabular}

Table 2. Total polyphenol and flavonoid contents of Cinnamomum cassia bark extracts

\begin{tabular}{lcc}
\hline & WE & EE \\
Total polyphenol & $90.12 \pm 1.03 \mu \mathrm{g} / \mathrm{mL}$ & $113.07 \pm 0.64 \mu \mathrm{g} / \mathrm{mL}$ \\
Total flavonoid & $34.42 \pm 1.01 \mu \mathrm{g} / \mathrm{mL}$ & $54.31 \pm 1.23 \mu \mathrm{g} / \mathrm{mL}$ \\
\hline
\end{tabular}

WE, water extract; EE, 70\% ethanol extract. 


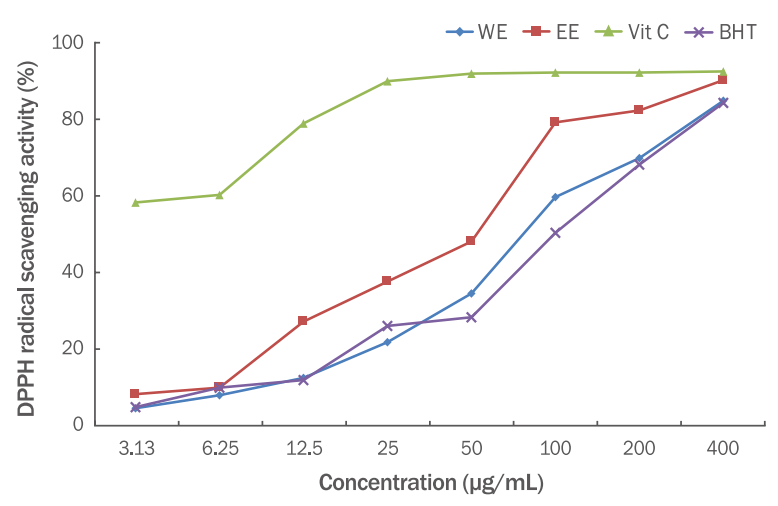

Figure 1. DPPH radical scavenging activities of Cinnamomum cassia bark extracts.

DPPH radical scavenging assays were conducted to investigate the anti-oxidant effects of Cinnamomum cassia bark in WE and $\mathrm{EE}$ at varying concentration levels of $3.13,6.25,12.5,25,50$, 100,200 , and $400 \mu \mathrm{g} / \mathrm{mL}$. WE, water extracts; $\mathrm{EE}, 70 \%$ ethanol extracts; Vit C, ascorbic acid; BHT, butylated hydroxytoluene group; DPPH, 1,1-diphenyl-2-picrylhydrazyl.

는 계피 추출물에 존재하는 폴리페놀 및 플라보노이드 함량을 각 각 tannic acid, naringin을 기준 물질로 하여 측정하였다. 계 피 에탄올, 열수 추출물 $1 \mathrm{mg} / \mathrm{mL}$ 농도에서 총 폴리페놀 함량 은 tannic acid 표준 곡선으로 하여 측정한 결과, $90.12 \pm 1.03$, $113.07 \pm 0.64 \mu \mathrm{g} / \mathrm{mL}$ 으로 나타났다(Table 2). Naringin을 표 준 곡선으로 플라보노이드 함량을 측정한 결과 계피 열수, 에탄 올 추출물 $1 \mathrm{mg} / \mathrm{mL}$ 농도에서 $36.42 \pm 1.01,54.31 \pm 1.23 \mu \mathrm{g} /$ $\mathrm{mL}$ 로 나타났다(Table 2).

\section{DPPH radical 소거능}

$\mathrm{DPPH}$ 는 비교적 안정한 free radical로써 수소를 공여 받 아 환원되어 짙은 자색이 노란색으로 탈색되는 원리를 이용하 여 간단히 항산화 활성을 측정 할 수 있는 동시에 다양한 천연 물질의 자유 라디칼 소거능 측정에 널리 사용되고 있다(Pak et al., 2014). 계피 추출물의 DPPH radical 소거능을 측정한 결과 $3.13-400 \mu \mathrm{g} / \mathrm{mL}$ 농도에서, 열수 추출물은 $4.86,8.13,12.60$, $21.95,34.55,59.72,69.91,84.93 \%$ 의 소거능이, 그리고 에 탄올 추출물은8.54, 10.27, 27.26, 37.75, 48.22, 79.14, $82.21,90.25 \%$ 의 소거능이 확인 되었다. 양성 대조군으로 사 용된 Vit C의 DPPH radical 소거능은 58.22, 60.31, 78.81, $89.84,91.81,92.29,92.3,92.5 \%$ 로 확인되었고, BHT의 경 우 $5.21,10.22,12.08,26.32,28.36,50.49,68.31,84.38 \%$ 로 확인되었다(Figure 1). 계피 에탄올 추출물은 Vit C 보다는 소거능이 낮지만 $400 \mu \mathrm{g} / \mathrm{mL}$ 의 농도에서는 BHT보다 높은 소거 능이 확인되었다.

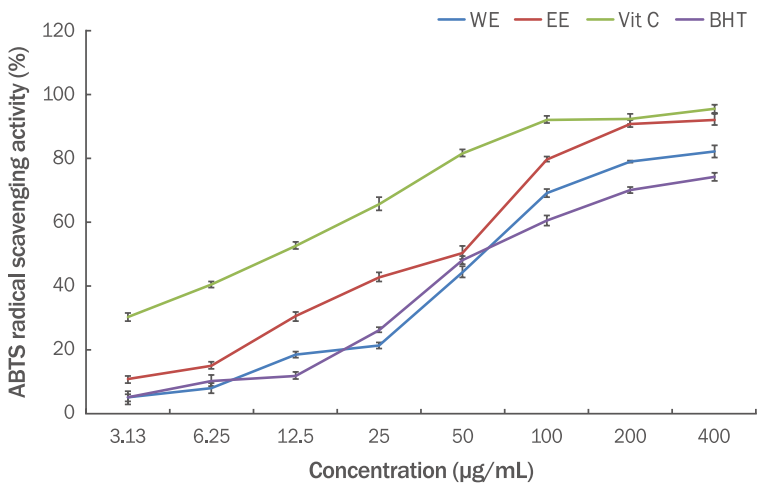

Figure 2. ABTS radical scavenging activities of Cinnamomum cassia bark extracts.

ABTS radical scavenging activities assays were conducted to investigate the anti-oxidant effects of Cinnamomum cassia bark in WE and EE at varying concentration levels of 3.13, 6.25, $12.5,25,50,100,200$, and $400 \mu \mathrm{g} / \mathrm{mL}$. WE, water extracts; EE, 70\% ethanol extracts; Vit C, ascorbic acid; BHT, butylated hydroxytoluene group.

\section{ABTS 라디칼 소거활성}

$\mathrm{ABTS}$ 라디칼 소거능은 항산화제의 유무를 확인하는 것으 로 radical을 생성하는 ABTS 존재 시 hydrogen peroxide와 metmyoglobin의 활성을 토대로 보다 빠른 항산화 반응을 일 으켜 myoglobin radical을 감소시키는 기전이라고 할 수 있다 (Kim et al., 2012). 계피 추출물의 ABTS radical 소거능을 측 정한 결과 3.13-400 $\mu \mathrm{g} / \mathrm{mL}$ 농도에서, 열수 추출물은 5.14 , $8.25,18.60,21.50,44.55,69.22,79.01,82.20 \%$ 의 소거 능이, 그리고 에탄올 추출물은 $10.89,15.24,30.60,42.95$, $50.55,79.72,90.91,92.12 \%$ 의 소거능이 확인 되었다. 양 성 대조군으로 사용된 Vit C의 $\mathrm{ABTS}$ 소거능은 $30.46,40.61$, $52.71,65.81,81.71,92.19,92.30,95.50 \%$ 로 확인되었 고, $\mathrm{BHT}$ 의 경우 $5.19,10.54,12.08,26.32,48.16,60.49$, $70.11,74.38 \%$ 로 확인되었다(Figure 2). 계피 추출물의 농도가 증가할수록 $\mathrm{ABTS}$ 라디컬 소거활성이 증가함을 볼 수 있고, 열수 추출물보다는 에탄올 추출물에서 더 효과적인 것을 확인할 수 있 었다.

\section{RAW 264.7 세포에서LPS에 대한 항염증 효과}

\section{1) 세포 생존율}

대식 세포는 혈액 단핵세포로부터 분화한 조직 세포로 염증 반 응에서 방어적 역할을 담당한다(Park et al., 2015).

계피 추출물이 마우스 대식세포주인 RAW 264.7 세포에 미치 는 영향을 알아보기 위해 1-200 $\mu \mathrm{g} / \mathrm{mL}$ 까지 다양한 농도로 처 리하여 세포생존율을 확인한 결과, 시료의 처리 농도 의존적으 로 세포 독성이 더 강해지는 것을 관찰하였으며, 다음 실험에 적 


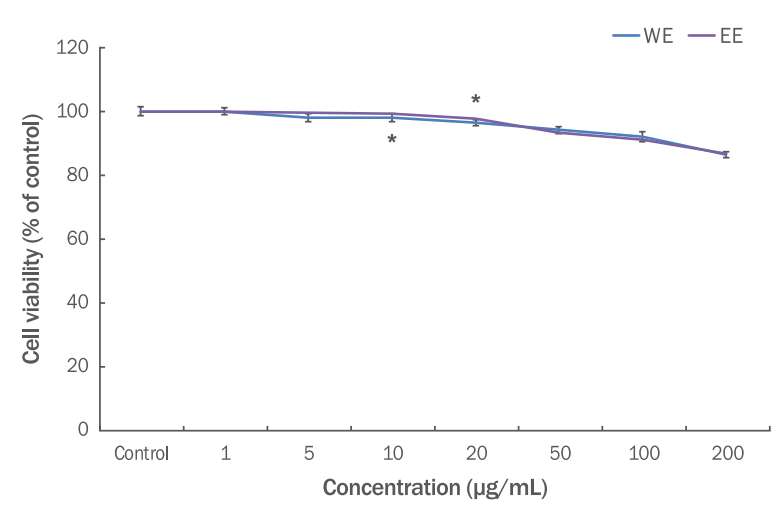

Figure 3. Effects of Cinnamomum cassia bark extracts on the viability of RAW 264.7 cells.

RAW 264.7 cells were incubated with Cinnamomum cassia bark extracts at varying concentration levels $(1,5,10,20,50,100$, and $200 \mu \mathrm{g} / \mathrm{mL}$ ) for $24 \mathrm{~h}$. Results are presented as the $\mathrm{M} \pm \mathrm{S}$. D. of three independent experiments. Statistically significant differences are indicated with an asterisk $\left({ }^{*} p<0.05\right.$, compared with the control). WE, Water extracts; EE, 70\% ethanol extracts; $M \pm S . D .$, mean \pm standard deviation.

용할 계피 추출물의 농도는 생존율이 $90 \%$ 이상(열수 추출물: $92.13 \%$, 에탄올 추출물: $91.18 \%$ )이 되는 $100,50,20,10,5$, $1 \mu \mathrm{g} / \mathrm{mL}$ 농도를 적용하였다(Figure 3).

\section{2) RAW 264.7 세포에서 NO 저해 효과 측정}

$\mathrm{NO}$ 는 염증인자로서 여러 가지 만성 염증성 질환을 유발하는 주용 원인이 되며, 염증이 발생하게 되면 대식세포가 활성화되어 $\mathrm{NO}$ 를 생성하여 이에 의해 활성화된 백혈구와 대식세포에 의해 이물질을 제거한 후 조직재생을 통해 종료 되지만 과량의 $\mathrm{NO}$ 는 피부질환, 천식, 퇴행성 신경질환, 당뇨 등을 유발하는 것으로 알려져 있다(Lee et al., 2017b). NO의 생성량은 RAW 264.7 세포의 배양액 중에 LPS자극으로 유도된 NO의 함량을 측정하는 것으로 세포의 생존율에 영향을 미치지 않는 $1,5,10,20,50$, $100 \mu \mathrm{g} / \mathrm{mL}$ 의 농도에서 계피 추출물을 처리하여 배양한 후, 세 포 배양액에 Griess시약을 반응시켜 확인하였다. 시료는 1-100 $\mu \mathrm{g} / \mathrm{mL}$ 의 농도로 처리하였으며, 대조군으로는 시료 대신 PBS를 사용하여 LPS를 처리 한 control과 시료 및 LPS를 처리하지 않 은 blank를 사용하였다. LPS를 처리한 control은 NO의 생성량 이 $20.11 \mu \mathrm{M}$ 로 높게 나타났으며, LPS를 처리하지 않은 blank 는 $\mathrm{NO}$ 의 생성량이 $0.41 \mu \mathrm{M}$ 로 상대적으로 매우 낮게 나타났 다. LPS에 의해 염증 반응이 유도된 세포에 계피 추출물을 1,5 , $10,20,50,100 \mu \mathrm{g} / \mathrm{mL}$ 로 처리한 결과, 열수 추출물에서는 농 도별로 각각 $20.24,20.14,18.78,17.25,16.08,14.57 \mu \mathrm{M}$ 까 지 NO 생성량이 감소하였고, 에탄올 추출물에서는 농도별로 각

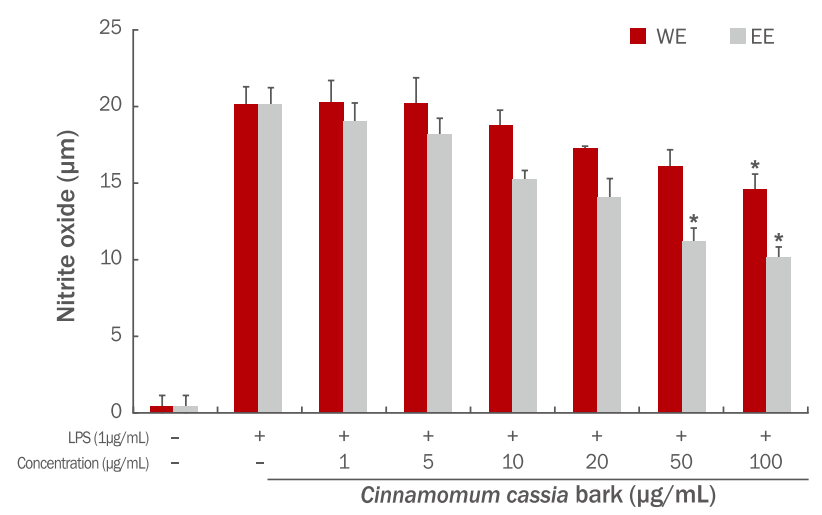

Figure 4. Effects of Cinnamomum cassia bark extracts on NO production in LPS-stimulated RAW 264.7 cells.

RAW 264.7 cells were treated with varying concentrations of Cinnamomum cassia bark extracts for $1 \mathrm{~h}$, and stimulated with or without LPS ( $1 \mu \mathrm{g} / \mathrm{mL})$ for $24 \mathrm{~h}$. NO concentration in the medium was determined using the Griess assay. Results are represented as $\mathrm{M} \pm$ S.D. of three independent experiments. Statistically significant differences are indicated with asterisks $\left({ }^{*} p<0.05\right.$, compared with the control). WE, water extracts; EE, 70\% ethanol extracts; LPS, lipopolysaccharide; NO, nitric oxide; M \pm S.D., mean \pm standard deviation.

각 $19.00,18.15,15.18,14.05,11.18,10.15 \mu \mathrm{M}$ 까지 $\mathrm{NO}$ 생 성량이 감소하였다. LPS에 의해 $\mathrm{NO}$ 의 생성량이 $20.11 \mu \mathrm{M}$ 까지 증가된 것에 비해 $50,100 \mu \mathrm{g} / \mathrm{mL}$ 의 농도에서는 열수 추출물은 $16.08,14.57 \mu \mathrm{M}$ 로, 에탄올 추출물은 $11.18,10.15 \mu \mathrm{M}$ 까지 감소된 것으로 보아 계피 추출물의 NO 생성을 유의적으로 감소 시켰으므로 계피는 피부의 염증개선에 도움을 줄 수 있다고 해석 할 수 있었다(Figure 4).

\section{RBL-2H3 세포에서 항히스타민 활성 \\ 1) $\mathrm{RBL}-2 \mathrm{H} 3$ 세포에 관한 MTT 측정 결과}

항히스타민 활성 측정을 위해 $\mathrm{IgE}$ 로 감작된 $\mathrm{RBL}-2 \mathrm{H} 3$ 세포 에 대한 추출용매에 따른 계피 추출물 $(1-200 \mu \mathrm{g} / \mathrm{mL})$ 을 처리한 후 세포 독성을 측정한 결과, $100 \mu \mathrm{g} / \mathrm{mL}$ 이하의 농도에서는 세 포 독성이 관찰되지 않았다(Figure 5). 다음 실험에 적용할 계 피 추출물의 농도는 생존율이 $90 \%$ 이상(열수 추출물: $92.60 \%$, 에탄올 추출물: $90.43 \%$ )이 되는 $100,50,20,10,5,1 \mu \mathrm{g} / \mathrm{mL}$ 농도를 적용하였다.

\section{2) 항히스타민 활성 측정 결과}

히스타민은 즉시형 과민반응과 소양감을 유발하는 주요 매 개체로서 아토피 환자에게 특이적으로 혈장 히스타민 농도 가 높아지는 것으로 알려져 있다(Jeong et al., 2009). 따라 서 본 연구에서는 계피 추출물을 이용하여 소양감을 줄이고 


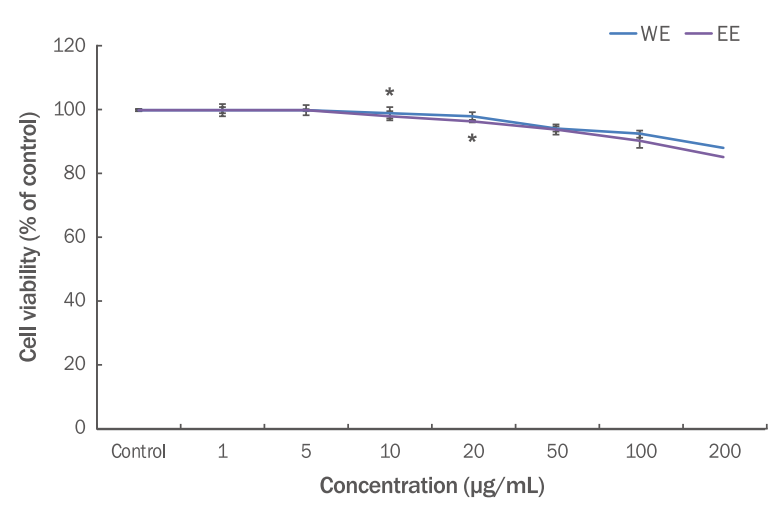

Figure 5. Effect of the Cinnamomum cassia bark extracts on the cell viability of RBL-2H3 cells.

Cells were incubated with Cinnamomum cassia bark extracts $(1$, $5,10,20,50,100$, and $200 \mu \mathrm{g} / \mathrm{mL}$ ) for $24 \mathrm{~h}$ and cell viability was measured using an MTT assay. Results are presentedre as M \pm S.D. of three independent experiments. "represents $p<0.05$ compared with the control. WE, water extracts; EE, 70\% ethanol extracts; MTT, 3-(4,5-dimethylthiazol-2-yl)-2,5-diphenyltetrazolium bromide; $M \pm S . D .$, mean \pm standard deviation.

자 $\mathrm{RBL}-2 \mathrm{H} 3$ 으로부터 히스타민 유리능의 지표로 사용되고 있 는 $\beta$-hexosaminidase의 방출억제를 조사하였다. 계피 추출물 1-100 $\mu \mathrm{g} / \mathrm{mL}$ 의 농도로 처리하였으며, 대조군으로는 시료 대 신 PBS를 사용하여 $\mathrm{IgE}-\mathrm{DNP}(500 \mathrm{ng} / \mathrm{mL})$ 를 처리 한 control 과 계피 추출물 및 $\mathrm{IgE}-\mathrm{DNP}$ 를 처리하지 않은 blank를 사용 하였다. IgE-DNS를 처리한 control은 $167.21 \%$ 로 증가하였으 며, 계피 추출물을 $1,5,10,20,50,100 \mu \mathrm{g} / \mathrm{mL}$ 로 처리한 결 과, 열수 추출물에서는 농도별로 각각 $167.90,160.71,155,22$ $140.25,135.41,117.25 \%$ 으로 $\beta$-hexosaminidase의 억제 가 확인 되었으며, 에탄올 추출물에서는 각각 $161.10,151.52$, $134.83,120.11,115.53,100.09 \%$ 으로 $\beta$-hexosaminidase의

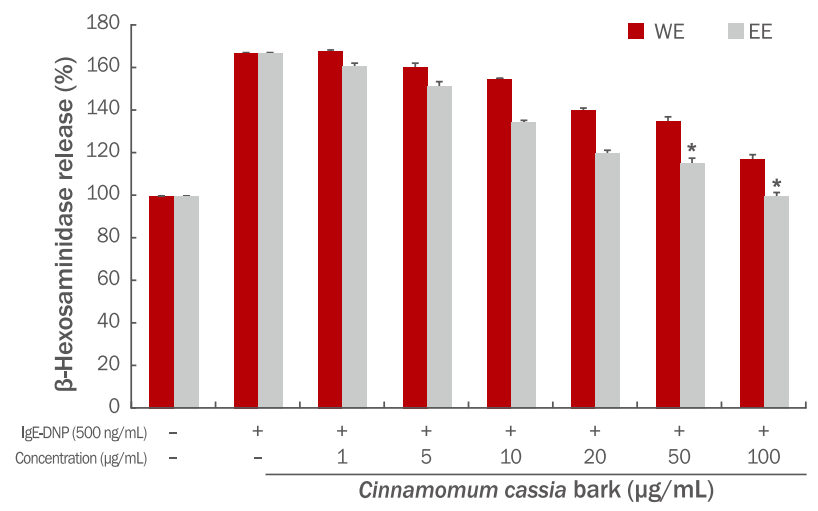

Figure 6. Inhibitory effect of Cinnamomum cassia bark extracts on $\beta$-hexosaminidase release in IgE-antigen complex-stimulated RBL-2H3 cells.

The release of $\beta$-hexosaminidase in lgE-antigen complex-stimulated RBL-2H3 cells were measured to investigate the inhibitory effect of Cinnamomum cassia bark extracts at different concentrations (1, $5,10,20,50$ and $100 \mu \mathrm{g} / \mathrm{mL})$. Results are represented as $\mathrm{M} \pm \mathrm{S}$. D. of the three independent experiments. *represents $p<0.05$ compared with the control. WE, water extraction; EE, 70\% ethanol extraction; M \pm S.D., mean \pm standard deviation.

억제가 확인 되었다. 계피 추출물은 농도 의존적으로 억제효과가 확인 되었으며, 특히 $50,100 \mu \mathrm{g} / \mathrm{mL}$ 에서 유의성이 확인 되었다 (Figure 6).

\section{6. 계피 추출물의 항균 효과}

피부는 외부환경과 항상 접하고 있는 기관으로, 외부로부터 인 체를 보호하는데 중요한 역할을 담당하고 있다. 그러나 인간의 피부에 상주하는 다양한 균들에 의해서 많은 피부질환들이 발생 하고 있는데, 그 중 가장 대표적인 질환으로 비듬 및 지루성 피부 염, 여드름 그리고 무좀 등을 꼽을 수 있다(Ha et al., 2009). 계 피 추출물 $0.25-5 \mathrm{mg} / \mathrm{mL}$ 농도에서 clear zone 수치는 Table

Table 3. Antimicrobial activity of Cinnamomum cassia bark extracts

\begin{tabular}{|c|c|c|c|c|c|c|c|c|c|}
\hline \multirow{3}{*}{ Bacteria } & \multicolumn{9}{|c|}{ Inhibition zone diameter (mm) } \\
\hline & \multicolumn{2}{|c|}{$5(\mathrm{mg} / \mathrm{mL})$} & \multicolumn{2}{|c|}{$1(\mathrm{mg} / \mathrm{mL})$} & \multicolumn{2}{|c|}{$0.5(\mathrm{mg} / \mathrm{mL})$} & \multicolumn{2}{|c|}{$0.25(\mathrm{mg} / \mathrm{mL})$} & \multirow{2}{*}{$\begin{array}{l}\text { Control } \\
\text { Ethanol }\end{array}$} \\
\hline & WE & $\mathrm{EE}$ & WE & $\mathrm{EE}$ & WE & $\mathrm{EE}$ & WE & $\mathrm{EE}$ & \\
\hline S. epidermidis & 5 & 8 & 4 & 6 & 1 & 4 & 1 & 3 & $-1)$ \\
\hline S. aureus & 4 & 6 & 2 & 4 & 2 & 2 & 1 & 2 & - \\
\hline P. acnes & 4 & 7 & 2 & 6 & 2 & 5 & 1 & 3 & - \\
\hline E. coli & 4 & 6 & 2 & 4 & 1 & 3 & - & 1 & - \\
\hline P. ovale & 6 & 8 & 2 & 6 & 1 & 4 & 1 & 3 & - \\
\hline M. furfur & 6 & 7 & 3 & 5 & 2 & 3 & - & 2 & - \\
\hline C. albicans & 4 & 7 & 2 & 5 & - & 3 & - & 2 & - \\
\hline T. mentagrophytes & 5 & 8 & 2 & 6 & 2 & 5 & 1 & 3 & - \\
\hline
\end{tabular}

${ }^{1)}$ No inhibition.

WE, water extract; EE, 70\% ethanol extract; S. epidermidis, Staphylococcus epidermidis; S. aureus, Staphylococcus aureus; P. acnes, Propionibacterium acnes; E. coli, Escherichia coli; P. ovale, Pityrosporum ovale; M. furfur, Malassezia furfur; C. albicans, Candida albicans; T. mentagrophytes, Trichophyton mentagrophytes. 
3 과 같이 확인 되었다. 8종의 균에 대한 항균활성 실험 결과, 5 $\mathrm{mg} / \mathrm{mL}$ 농도에서 열수 추출물은 P. ovale, Malassezia furfur ( $M$. furfur) $\rangle S$. epidermidis, Trichophyton mentagrophytes (T. mentagrophytes) $>$ Staphylococcus aureus ( $S$. aureus), Propinibacterium acnes (P. acnes), Escherichia coli (E. coli), Candida albicans (C. albicans) 균 순으로 clear zone 수치가 $6,6>5,5>4,4,4,4 \mathrm{~mm}$ 로 확인 되었다. 에탄올 추출물 은 $S$. epidermidis, P. ovale, T. mentagrophytes $>P$. acnes, M. furfur, C. albicans $>S$. aureus, E. coli 균 순으로 clear zone 수치가 $8,8,8>7,7,7>6,6 \mathrm{~mm}$ 로 확인 되었다.

\section{Conclusion}

본 연구에서는 계피 추출물의 천연 기능성 화장품 소재로서 의 사용 가능성에 대하여 확인하고자 하였다. 계피 열수 그리고 에탄올 추출물을 이용하여 총 폴리페놀, 총 플라보노이드 함량, $\mathrm{DPPH}$ radical 소거활성 및 $\mathrm{ABTS}$ 라디칼 소거활성을 조사하여 항산화 효과를 확인하였으며, LPS로 염증반응이 유도된 RAW 264.7 세포를 통해 NO 생성 저해 효과와 RBL- $2 \mathrm{H} 3$ 세포에서 항히스타민 활성을 알아보았다. 그리고8종의 균에 대한 계피 추 출물의 항균효과도 확인한 결과 다음과 같다.

항산화 효과 측정 결과, 계피 에탄올, 열수 추출물의 총 폴리 페놀 함량은 각각 $90.12,113.07 \mu \mathrm{g} / \mathrm{mL}$ 이고, 총 플라보노이 드 함량은 $36.42,54.31 \mu \mathrm{g} / \mathrm{mL}$ 으로 확인 되었다. $\mathrm{DPPH}$ 소 거활성은 $400 \mu \mathrm{g} / \mathrm{mL}$ 에서 열수 추출물은 $84.93 \%$, 에탄올 추 출물은 $90.25 \%$ 의 소거능이 확인 되었으며, ABTS 라디칼 소거 활성을 측정 결과, $400 \mu \mathrm{g} / \mathrm{mL}$ 에서 열수 추출물은 82.20 , 에 탄올 추출물은 $92.21 \%$ 의 소거능이 확인 되었다. LPS로 염증 반응이 유도된 RAW 264.7 세포를 통해 NO 저해 효과 측정 결 과, $\mathrm{LPS}$ 에 의해 $\mathrm{NO}$ 의 생성량이 $20.11 \mu \mathrm{M}$ 까지 증가된 것에 비해 $100 \mu \mathrm{g} / \mathrm{mL}$ 의 농도에서는 열수 추출물은 $14.57 \mu \mathrm{M}$, 에 탄올 추출물은 $10.15 \mu \mathrm{M}$ 까지 감소된 것으로 보아 계피 추출 물의 $\mathrm{NO}$ 생성 억제 효과를 확인할 수 있었다. RBL-2H3 세 포에서 항히스타민 활성을 측정한 결과, $\mathrm{IgE}-\mathrm{DNP}$ 에 의해 $\beta$-hexosaminidased이 $167.21 \%$ 로 증가된 것에 비해 $100 \mu \mathrm{g} /$ $\mathrm{mL}$ 의 농도에서는 열수 추출물은 $117.25 \%$ 에탄올 추출물은 $100.09 \%$ 로 $\beta$-hexosaminidase 방출에 대한 억제 효과를 확인 할 수 있었다. 8종 균에 대한 계피 추출물의 추출물의 항균효과 를 측정한 결과 모든 균에서 항균효과가 확인 되었으며 특히 $S$. epidermidis, P. ovale에서 열수 추출물과 에탄올 추출물 항균 효과가 높게 확인되었다.

이러한 결과, 계피 추출물은 항산화 효과 및 항염 효과 및 항 히스타민 억제효과 그리고 항균효과가 우수하였으며, 천연 기능
성 화장품 소재로서의 가능성이 있다고 판단된다.

\section{References}

Blois MS. Antioxidant determinations by the use of a stable free radical. Nature, 181: 1199-1200, 1958.

Cho WG, Park HS, Ahn BJ. Antimicrodial activities of sophorolipids and its application for cosmetics. Journal of the Society of Cosmetic Scientists of Korea, 34: 317323, 2008.

Folin O, Denis W. A colorimetric method for the determination of phenols (and phenol derivatives) in urine. Journal of Biological Chemistry, 22: 305-308, 1915.

Jeong YS, Jung HK, Youn KS, Kim MO, Hong JH. Physiological activities of hot water extract from Eriobotrya japonica Lindl. Journal of the Korean Society of Food Science and Nutrition, 38: 977-982, 2009.

Jo IJ, Choi MO, Park MC, Song HJ, Park SJ. Anti-Inflammatory effect of aqueous extract of Scolopendrae corpus in RAW 264.7 cell. The Korean Journal of Herbology, 26: 23-29, 2011.

Ha YM, Lee BB, Bae HJ, Je KM, Kim SR, Choi JS, Choi IS. Anti-microbial activity of grapefruit seed extract and processed solution against human skin pathogens. Journal of Life Science, 19: 94-100, 2009.

Hong IK, Kim EJ, Seok JH, Kim BH, Jang JD, Joe GJ, Choi SW. Effects of Eucommia ulmoides Oliver extract on inhibition $\beta$-hexosaminidased and keratinocyte differentiation. Journal of the Society of Cosmetic Scientists of Korea, 40: 21-28, 2014.

Huh CK, Shim KH. Quality characteristics of sourdough bread added with lactic acid bacteria culture solution and cinnamon extract. Korean Journal of Food Preservation, 24: 764-770, 2017.

Kim CH, Hwang DS, Kim JT, Jung HA, Roh SS, Lim NK. A randomized study, double-blind, placebo-controled study to herbal shampoo \& essence about dandruff. The Journal of Korean Oriental Medical Ophthalmology \& Otolaryngology \& Dermatology, 20: 222-235, 2007.

Kim BH, Song WS. The dyeability and antimicrobial properties of Cinnamoum cassia by mordants concehtration. Fashion \& Textile Research Journal, 3: 162-167, 2001. 
Kim HJ, Lim HW, Choi SW, Yoon CS. Antimicrobial effect of ethanol extract of Dryopteris crassirhizoma Nakai on Propionibacterium acnes. Journal of the Society of Cosmetic Scientists of Korea, 32: 201-208, 2006.

Kim KH, Kim HJ, Byun MW, Yook HS. Antioxidant and antimicrobial activities of ethanol extract from six vegetables containing different sulfur compounds. Journal of the Korean Society of Food Science and Nutrition, 41: 577-583, 2012.

Kim M, Park S. Effects of Corchorus olitorius L. (Molokhia) extracts as functional cosmetic materials. Asian Journal of Beauty and Cosmetology, 15: 23-31, 2017.

Kim SH, Jang HJ. Study on the bioactive characteristics of Morinda citrifolia as a cosmetic raw material. Journal of the Society of Cosmetic Scientists of Korea, 42: 183193, 2016.

Kim WI. Experimental study about pathway of aconiti ciliare tuber on allergic reaction of inflammation. Korean Journal of Oriental Medicine, 16: 155-166, 2010.

Lee AR, Roh SS, Kim HK. Anti-microbial activity and antiinflammatory effects of fucoidan extracts. Asian Journal of Beauty and Cosmetology, 16: 191-200, 2018.

Lee HJ, Son DJ, Kang MH, Lee BC, Hong JT. Effects of lignan compound of sesame on LPS-induced nitric oxide generation in murine macrophage RAW 264.7 cells. Journal of the Society of Cosmetic Scientists of Korea, 32: 173-180, 2006.

Lee JY, Yoo DH, Jo DH, Kim SR, Jo HS, Joo SH, Chae JW. Anti-inflammatory effects of Amelanchier asiatica fruits ethanol extract. Journal of the Society of Cosmetic Scientists of Korea, 43: 19-26, 2017 a.

Lee YK, Kim CT, Choi HJ. Anti-inflammatory effect of Anemarrhenae Rhizoma 80\% ethanol extract in RAW 264.7 cells. The Korea Journal of Herbology, 32: 97103, $2017 \mathrm{~b}$.

Lee SY, Kim BA, Shin DC. A study of antimicrobial effect of Zostera marina extracts. Journal of Oil \& Applied Science, 33: 225-231, 2016.

Nam JJ, Kim YJ. Fractionated Trapa japonica extracts inhibit ROS-induced skin inflammation in HaCaT keratinocytes. Journal of the Society of Cosmetic Scientists of Korea, 41: 45-55, 2015.

Park SH, Jeong JH, Park BJ, Jeong TH. Anti-inflammatory effect of Fallopia sachalinensis RonseDecr. fruit. Journal of the Society of Cosmetic Scientists of Korea, 41: 237241, 2015.

Park SJ, Yu MH, Kim JE, Lee SP, Lee IS. Comparison of antioxidant and antimicrobial activities of supercritical fluid extracts and Marc extracts from Cinnamomum verum. Journal of Life Science, 22: 373-379, 2012.

Pak WM, Kim KBWR, Kim MJ, Kang BK, Bark SW, Kim BR, Ahn NK, Choi YU, Yoon SR, Ahn DH. Antioxidative effect of extracts from different parts of Kohlrabi. Journal of Applied Biological Chemistry, 57: 353-358, 2014.

Shim JH. Anti-inflammatory Effect of Galium aparine extract in RAW 264.7 cells. Asian Journal of Beauty and Cosmetology, 16: 233-242, 2018. 


\section{국문초록}

\section{계피 추출물의 항산화 효과 및 화장품소재의 응용}

이영숙, 유민정

남부대학교 향장미용학과, 광주, 한국

목적: 본 연구에서는 계피 추출물의 생리활성 및 화장품 소재로서의 가능성과 산업적 활용가치를 확인하고자 하였다. 방법: 계피 를 열수 그리고 $70 \%$ 에탄올로 추출물하여 이용하여 총 폴리페놀, 플라보노이드 함량, 2,2-Diphenyl-1-picrylhydrazyl (DPPH) 소 거활성, ABTS radical 소거활성을 조사하여 항산화 효과를 확인하였으며, lipopolysaccharides (LPS)로 염증반응이 유도된 RAW 264.7 세포를 통해 nitric oxide $(\mathrm{NO})$ 생성 저해 효과와 RBL-2H3세포에서 항히스타민 활성을 알아보았다. 그리고 8종의 균에 대 한 계피 추출물의 항균효과도 확인 하였다. 결과: 항산화 효과 측정 결과, 총 폴리페놀 함량은 각각 $90.12,113.07 \mu \mathrm{g} / \mathrm{g}$ 이고, 총 플 라보노이드 함량은 $36.42,54.31 \mu \mathrm{g} / \mathrm{g}$ 의 함량이 확인 되었다. DPPH 소거활성은 $400 \mu \mathrm{g} / \mathrm{mL}$ 에서 열수 추출물은 $84.93 \%$, 에탄올 추출물은 $90.25 \%$ 의 소거능이 확인 되었으며, ABTS 라디칼 소거활성을 측정 결과, $400 \mu \mathrm{g} / \mathrm{mL}$ 에서 열수 추출물은 $82.20 \%$, 에탄올 추출물은 92.21\%의 소거능이 확인 되었다. LPS로 염증반응이 유도된 RAW 264.7 세포를 통해 NO 저해 효과 측정 결과, LPS에 의 해 $\mathrm{NO}$ 의 생성량이 $20.11 \mu \mathrm{M}$ 까지 증가된 것에 비해 $100 \mu \mathrm{g} / \mathrm{mL}$ 의 농도에서는 열수 추출물은 $14.57 \mu \mathrm{M}$ 에탄올 추출물은 $10.15 \mu \mathrm{M}$ 까지 감소된 것으로 보아 계피 추출물의 $\mathrm{NO}$ 생성 억제 효과를 확인할 수 있었다. RBL- $2 \mathrm{H} 3$ 세포에서 항히스타민 활성을 측정한 결 과, $\mathrm{IgE}-\mathrm{DNP}$ 에 의해 $\beta$-hexosaminidased이 $176.21 \%$ 로 증가된 것에 비해 $100 \mu \mathrm{g} / \mathrm{mL}$ 의 농도에서는 열수 추출물은 $117.25 \%$ 에탄 올 추출물은 $100.09 \%$ 로 $\beta$-hexosaminidase 방출에 대한 억제 효과를 확인할 수 있었다. 8 종 균에 대한 계피 추출물의 추출물의 항 균효과를 측정한 결과 모든 균에서 항균효과가 확인 되었으며 특히 $S$. epidermidis, $P$. ovale 에서 열수 추출물과 에탄올 추출물 항 균효과가 높게 확인되었다. 결론: 계피 추출물은 항산화 효과 및 항염 효과 및 항히스타민 억제효과 그리고 항균효과가 우수하였으 며, 천연 기능성 화장품 소재로서의 가능성이 있다고 판단된다.

핵심어: 계피, 항산화, 항염증, 항균효과, 화장품

\section{참고문헌}

김경희, 김혜정, 변명우, 육홍선. 황 함유 채소 에탄올 추출물의 항산화 및 항균활성. 한국식품영양과학회지, $41: 577-$ $583,2012$.

김미정, 박세연. 기능성 화장품 소재로서 몰로키아 추출물의 가능성. 아시안뷰티화장품학술지, 15: 23-31, 2017

김병희, 송화순. 매염제 농도에 따른 계피의 염색성 및 항균성. 한국의류산업학회지, 3: 162-167, 2001.

김승희, 장혜진. 화장품 소재로서의 노니 추출물에 관한 특성연구. 대한화장품학회지. 42: 189-193, 2016.

김원일. 초오의 항알레르기 염증반응 및 기전탐색에 관한 연구. 한국한의학연구원논문집, 16: 155-166, 2010.

김현주, 임혜원, 최신욱, 윤창순. 관중(Dryopteris crassirhizoma Nakai) 추출물의 Propionibacterium acnes에 대한 항

균 효과. 대한화장품학회지, 32: 201-208, 2006.

김창훈, 황동성, 김정태, 정현아, 노석선, 임남규. 한방 샴푸/에센스의 비듬에 대한 무작위배정, 이중맹검, 위약 대조군 연

구. 한방안이비인후피부과학회지, 20: 222-235, 2007.

남진주, 김연준. 각질형성세포에서 $\mathrm{ROS}$ 로 유도된 염증반응에 대한 능실 추출물 및 그 분획물의 항염 효과. 대한화장품학

회지, 41: 45-55, 2015.

박성진, 유미희, 김지은, 이삼빈, 이인선. 계피 초임계 추출물 및 박 추출물의 항균·항산화 활성 비교. 생명과학회지, 22 :

373-379, 2012.

박성하, 정현정, 박병준, 정태화. 왕호장 열매의 항염증 효과. 대한화장품학회지, 41: 237-241, 2015. 
박원민, 김꽃봉우리, 김민지, 강보경, 박시우, 김보람, 안나경, 최연욱, 윤성열, 안동현. 콜라비 부위별 추출물의 항산화 효

과. 한국응용생명화학회지, $57: 353-358,2014$.

심중현. 갈퀴덩굴 추출물에 의한 RAW 264.7 세포에서의 항염 효과. 아시안뷰티화장품학술지, 16: 233-242, 2018.

이소연, 김보애, 신동철, 박관순, 양재찬. 잘피(Zostera marina) 추출물의 항균효과에 대한 연구. 오일 및 응용과학 학회 지, 33: 225-231, 2016.

이아름, 노성수, 김현경. 후코이단 추출물의 항균 및 항산화 효과. 아시안뷰티화장품학술지, 16: 191-200, 2018.

이영근, 김청택, 최학주. RAW 264.7 세포에서 지모 $80 \%$ 에탄올 추출물의 항염증 효과. 대한본초학회지, 32: 97-103, 2017.

이진영, 유단희, 주다혜, 김소라, 조희선, 주성현, 채정우. 채진목 에탄올 추출물의 항염증 효과 검증. 대한화장품학회지, 43: 19-26, 2017.

이화정, 손동주, 강명화, 이범천, 홍진태. 참깨의 리느난 화합물의 항염증 효과. 대한화장품학회지, 32: 173-180, 2006. 정유석, 정희경, 윤광섭, 김명옥, 홍주헌. 비파엽(Eriobotrya japonica Lindl.) 열수추출물의 생리활성. 한국식품영양과학 회지, 38: 977-982, 2009.

조일주, 최미옥, 박민철, 송호준, 박성주. 마우스 대식세포주인 RAW 264.7 세포에서 蜈蚣의 항염증 효과. 대한본초학회 지, 26: 23-29, 2011.

조완구, 박효순, 안병준. Sophorolipid의 항균효과와 화장품에의 응용. 대한화장품학회지, 34: 317-323, 2008.

하유미, 이보배, 배희정, 제경모, 김순래, 최재석, 최인순. 피부질환 원인균에 대한 자몽종자 추출물과 법제유황수의 항균 효과. 한국생명과학회지, 19: 94-100, 2009.

허창기, 심기훈. 유산균 배양액과 계피추출물을 첨가한 sourdough bread의 품질 특성. 한국식품저장유통학회지, 24 : 764-770, 2017.

홍인기, 김은지, 석지현, 김보현, 장진동, 조기정, 최신욱. $\beta$-hexosaminidased 분비 억제 및 각질형성세포 분화에 대한 두충(Eucommia ulmoides Oliver) 추출물의 효과. 대한화장품학회지, 40: 21-28, 2014. 


\section{中文摘要}

\section{肉桂树皮提取物的抗氧化作用及其作为化妆品成分的有效性}

李榮淑, 柳敏貞

南部大学香匠美容学科, 光州, 韩国

目的：探讨肉桂树皮提取物作为生物活性成分和化妆品成分的潜在能力和商业价值。方法: 用热水和 $70 \%$ 乙醇 提取肉桂树皮, 通过测定总多酚, 类黄酮含量, DPPH 自由基清除活性和ABTS自由基清除活性来检测其抗氧 化作用。另外，通过脂多糖（LPS）诱导炎症反应的RAW 264.7细胞中，检测其一氧化氮（NO）抑制作用; 在 RBL-2H3中检测抗组胺活性。研究肉桂树皮提取物对8种细菌的抑菌效果。结果: 通过测定抗氧化作用, 总多 酚含量分别为 90.12 和 $113.07 \mu \mathrm{g} / \mathrm{mL}$, 而总黄酮含量含量分别为 36.42 和 $54.31 \mu \mathrm{g} / \mathrm{mL}$ 。提取物浓度为 $400 \mu \mathrm{g} /$ $\mathrm{mL}$ 时, 热水提取物的DPPH的清除效果为 $84.93 \%$, 乙醇提取物中的DPPH清除效果为 $90.25 \%$ 。检测 ABTS自 由基结果显示，提取物浓度为 $400 \mu \mathrm{g} / \mathrm{mL}$ 时，热水提取物的效果为 $82.20 \%$, 乙醇提取物的效果为 $94.21 \%$ 。通 过LPS诱导炎症反应的RAW 264.7细胞测量NO抑制作用, 在提取物浓度为 $100 \mu \mathrm{g} / \mathrm{mL}$ 时, 热水提取物中NO产 生降低至14.57 $\mu \mathrm{M}$ ，乙醇提取物中NO 降低至10.15 $\mu \mathrm{M}$ 。与LPS增加至20.11 $\mu \mathrm{M}$ 相比，该结果显示肉桂树皮提 取物的NO抑制作用。测定RBL-2H3细胞中的抗组胺活性, IgE-NDP使 $\beta$-hexosaminidase增加至 $176.21 \%$, 而 提取物浓度为 $100 \mu \mathrm{g} / \mathrm{mL}$ 时，热水提取物中的 $\beta$-己糖胺酶为 $117.25 \%$ ，乙醇提取物中的为 $100.09 \%$ 。证实了对 $\beta$-hexosaminidase排放的抑制作用。检测肉桂树皮提取物对八种细菌的 (Cinnamomum cassia Bark) 抗菌作 用显示, 肉桂树皮提取物对所有细菌具有抗菌效果。特别地, 发现两种提取物对S. epidermidis, P. ovale具有 较高的抗菌作用。结论: 肉桂树皮提取物具有优异的抗氧化，抗炎，抗组胺抑制和抗菌作用，被认为是一种天然 功能性化妆品成分。

关键词: 肉桂树皮，抗氧化，抗炎，抗菌，化妆品 